\title{
XanoMatrix Surfaces as Scaffolds for Mesenchymal Stem Cell Culture and Growth [Expression of Concern]
}

\author{
Bhardwaj G, Webster $\mathrm{T}$. Int $J$ Nanomedicine. \\ 2016;11:2655-2661.
}

The Editor and Publisher of International Journal of Nanomedicine wish to issue an Expression of Concern for the published article.

Concerns were raised regarding the alleged duplication of regions shown in images from Figure 1A and Figure 1B.
International Journal of Nanomedicine would like to alert readers of this while we continue with our investigation.

The authors have been contacted and were informed of these concerns.

\section{Publish your work in this journal}

The International Journal of Nanomedicine is an international, peerreviewed journal focusing on the application of nanotechnology in diagnostics, therapeutics, and drug delivery systems throughout the biomedical field. This journal is indexed on PubMed Central, MedLine, CAS, SciSearch ${ }^{\mathbb{B}}$, Current Contents ${ }^{\mathbb{B}} /$ Clinical Medicine,
Journal Citation Reports/Science Edition, EMBase, Scopus and the Elsevier Bibliographic databases. The manuscript management system is completely online and includes a very quick and fair peer-review system, which is all easy to use. Visit http://www.dovepress.com/ testimonials.php to read real quotes from published authors. 